\title{
Molecular identification of Bifidobacterium sp. from local yoghurt and evaluation of growth inhibition activity against pathogenic bacteria
}

\author{
A. P. Talukder, M. N. Haque, M. L. Mahmud and M. A. E. Ekram ${ }^{1 *}$ \\ Department of Genetic Engineering and Biotechnology, University of Rajshahi, Rajshahi-6205, Bangladesh
}

Received: 15 December 2020

Revised: 06 June 2021

Accepted: 28 June 2021

DOI: https://doi.org/10.3329/bjsir.v56i3.55962

\begin{abstract}
Yoghurt is a potential source of probiotic bacteria including Bifidobacterium sp. In this context, sour yoghurt sample was collected from local market in Rajshahi for molecular identification and characterization of Bifidobacterium sp. with promising antagonistic activity against pathogenic bacteria. Isolation was done on Luria broth agar media for molecular identification and revealed that isolated bacterium showed $90 \%$ similarity with Bifidobacterium sp. Antibiotic sensitivity test result revealed that isolated Bifidobacterium sp. was sensitive to erythromycin, kanamycin, gentamycin, tetracycline, ciprofloxacin, doxycycline out of eleven commercially used antibiotics. Moreover, antagonistic activity of Bifidobacterium sp. was evaluated in our present study against four pathogenic bacteriathrough disc diffusion method. Bifidobacterium sp. had relatively strong antagonistic effect (inhibition zone $\geq 15 \mathrm{~mm}$ ) against Salmonella sp. with $16 \mathrm{~mm}$ and $19 \mathrm{~mm}$ zones of inhibition at doses of 150 and $200 \mu \mathrm{g} / \mathrm{disc}$, respectively. Similarly, the isolate showed strong growth inhibitory activity against Acinetobacter $\mathrm{sp}$. and $E$. coli with inhibition zone of $17 \mathrm{~mm}$ and $16 \mathrm{~mm}$ at dose of $200 \mu \mathrm{g} /$ disc while moderate growth inhibitory activity was observed against Aeromonas sp. at applied four doses. Furthermore, present investigation showed that the isolated Bifidobacterium sp. had the utmost effect against Salmonella sp. and exhibited growth inhibition of understudy pathogens in such pattern Salmonella sp.>Acinetobacter sp.> E. coli $>$ Aeromonas sp.
\end{abstract}

Keywords: Probiotics;16S rRNA gene; Bifidobacterium sp.; Antibiotic sensitivity; Growth inhibition activity

\section{Introduction}

Probiotics are live microorganisms intended to provide health benefits when consumed in adequate amounts, generally by improving or restoring the gut flora (Hill et al., 2014). Probiotics can be defined as 'viable microorganisms' that are used as food additives with beneficial effects on health by setting microbial balance in gastrointestinal tract (Hassanzadazar et al., 2012). Most common probiotic bacterial strains include Lactobacillus rhamnosus, Lactobacillus acidophilus, Lactobacillus plantarum, Bifidobacterium infantis, Bifidobacterium longum, Streptococcus thermophilus, Enterococcus faecium etc (Fijan, 2016). Probiotic bacteria play an important role in the protection of the organism against harmful microorganisms and strengthen the host's immune system when administered in appropriate quantities
(Pundir et al. 2013). Nowadays, probiotic microorganisms have been added into food as dietary adjuncts for improving human health as well as prevention of many diseases (Reyhaneh et al., 2018).

Bifidobacteria are generally considered to be food-grade organisms that do not impose health risks on the consumer. They are found in the intestinal tract of human and animal (Baivati et al., 2000) and have probiotic properties for promoting health (Matsuki et al., 2004). These organisms are frequently applied as probiotics in health-promoting dairy products and dried food supplements (Gomes and Malcata, 1999) because they play an essential role in maintaining the microbial balance of a healthy intestinal tract. 
Moreover, inco-administration with antibiotics in order to restore the intestinal health of the host, the presence of antimicrobial resistance in probiotic Bifidobacterium strains might be regarded as a desirable trait to allow their survival in the gastrointestinal tract. In addition, molecular identification has been used as a worldwide acceptable technique to identify any bacterium up to genus level across all major phyla. Generally, the identification is done using $16 \mathrm{~S}$ rRNA which is considered as the most reliable tools for identification of microorganism species (Shah, 2012). After isolation and characterization of bacteria it is necessary to identify the bacteria because only morphological and biochemical characterization cannot confirm the isolated species. The 16S rRNA is the most conserved gene in all cells and portions of the $16 \mathrm{~S}$ rRNA sequence from distantly related organisms are remarkably similar.

Recent concerns on the rampant and indiscriminate use of antibiotics for disease treatments, growth promotion of livestock and the development of antibiotic resistant pathogens have led to increase interest in the application of probiotics and their antimicrobial metabolites as alternative antimicrobial strategies for treatment and prevention of infections. Similarly,strong antibacterial activity of bifidobacteria towards gram negative bacteria, Salmonella and $E$. coli strains with the production of lactic and acetic acids as well as the inhibition of growth of gram positive bacteria with the production of a bacteriocin were reported (Makras and Vuyst, 2006).

Dairy product such as yogurt, is one of the best known foods which is mostly used as probiotic sources for transporting probiotic microorganisms to the human gastrointestinal tract (Tabanelli et al., 2016). In Bangladesh, yoghurt locally known as dahi is produced and consumed in large amount across the country (Shahnaz et al., 2004). However, despite growing interest in probiotics, there is a paucity of scientific research regarding emerging uses of yoghurts as probiotic sources in Bangladesh (Sultana et al., 2017). Development of probiotic products such as yoghurt with defined probiotic culture would be able to confer health benefits for mass and common people of Bangladesh. Therefore, our present research work was carried out to isolate, identify and characterize bacteria from yoghurt as potential probiotics with antimicrobial activity against microorganisms that are pathogenic to human.

\section{Materials and methods}

\section{Sample collection}

Sour yoghurt sample was purchased from local market in Saheb Bazar, Rajshahi, prior to the expiry date during
October, 2018. Sample was aseptically collected in sterile plastic container and transported to the Microbiology Laboratory, Dept. of Genetic Engineering and Biotechnology, University of Rajshahi, Bangladesh, in an insulated box with ice to maintain a temperature ranging from $4^{\circ} \mathrm{C}$ to $6^{\circ} \mathrm{C}$. Sample was processed within 6 hours of its collection.

\section{Enrichment of yoghurt bacteria}

The collected yoghurt sample was filtered by filter paper in a beaker. $5 \mathrm{ml}$ of each filtered yoghurt sample was added to $100 \mathrm{ml}$ LB liquid medium for enrichment as well as selection and incubated for $48-72 \mathrm{hr}$ at $37^{\circ} \mathrm{C}$ with shaking. Then the bacterial isolate was screened on nutrient agar (NA) plates. Plates were incubated at $37^{\circ} \mathrm{C}$ for $24 \mathrm{hr}$ and colonies differing in morphological characteristics were selected and used for further studies.

\section{Isolation and maintenance of pure culture}

Plating is essential to get single colony from mixed bacterial culture. Individual bacterial population was isolated from the above mentioned enrichment cultures by streak plate method on Luria Broth (LB) agar and plates were incubated at $37^{\circ} \mathrm{C}$ for $24 \mathrm{hr}$. The single colonies from these plates were sub cultured onto replicate plates and colonies from these eventually transferred into LB liquid medium. Pure strains were maintained by weekly passage in LB liquid medium and also by weekly subculture onto the LB agar medium.

\section{Molecular identification}

Molecular identification and characterization of the isolated bacterium was performed through the following steps: extraction of chromosomal DNA, amplification of 16S rRNA gene, purification of PCR products, cycle sequencing, purification of cycle sequencing products, detection of nucleotides and sequence analysis. The genomic DNA of the isolated bacterium was extracted using phenol/chloroform method. The 16S rRNA genes were amplified by PCR using $16 \mathrm{~S}$ rDNA specific forward primer $27 \mathrm{~F}$ 5'-AGAGTTTGATCMTGGCTCAG-3'and reverse primer 1492R 5'-GGTTACCTTGTTACGACTT-3'. The PCR reactions were carried out in thermal cycler (Applied Biosystem 9700, USA) using following amplification conditions: an initial denaturation step at $95^{\circ} \mathrm{C}$ for $5 \mathrm{~min}$, followed by 30 cycles of denaturation at $94{ }^{\circ} \mathrm{C}$ for $1 \mathrm{~min}$, annealing at $55^{\circ} \mathrm{C}$ for $1 \mathrm{~min}$, extension at $72{ }^{\circ} \mathrm{C}$ for $1 \mathrm{~min}$ and the final extension at $72^{\circ} \mathrm{C}$ for $10 \mathrm{~min}$. The $\mathrm{PCR}$ products were purified and were sequenced on both strands on genetic analyzer (Prism 310, USA). The sequences were then edited by bioinformatics software Chromas. 


\section{Antibiotic sensitivity test}

Antibiotic sensitivity and resistance pattern of the isolated probiotic bacterium was assayed according to the Kirby- Bauer disc diffusion method (Bauer et al., 1966). Commercially available and frequently prescribed antibiotics namely;

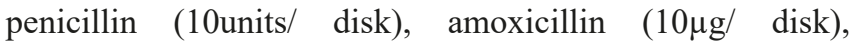
erythromycin $(15 \mu \mathrm{g} /$ disk), ampicillin $(10 \mu \mathrm{g} / \mathrm{disk})$, kanamycin $(30 \mu \mathrm{g} /$ disk), ceftazidime $(30 \mu \mathrm{g} /$ disk $)$, gentamycin $(10 \mu \mathrm{g} /$ disk), tetracycline $(30 \mu \mathrm{g} /$ disk $)$, ciprofloxacin $(5 \mu \mathrm{g} / \mathrm{disk})$, cefuroxime $(30 \mu \mathrm{g} / \mathrm{disk})$ and doxycycline $(30 \mu \mathrm{g} /$ disk $)$ were used as antibiotic disks.

\section{Preparation of media and culture plate}

The isolated bacterial strains were grown overnight in nutrient broths through orbital shaker at $37^{\circ} \mathrm{C}$ and $160 \mathrm{rpm}$ for the antibiotic sensitivity test. At first, LB agar medium was prepared, then for making culture plates, the sterile liquid medium was distributed in sterile petridishes. Approximately, (15-20) $\mathrm{ml}$ of the medium was poured in each petridish and left in the laminar airflow cabinet for solidification. $1 \mathrm{ml}$ of the overnight grown LB culture (O.D. = 0.5 ) for the isolated bacterium was poured into each nutrient plate and dried up. After overnight incubation at $37^{\circ} \mathrm{C}$, the zones were observed on the plates and were measured with the help of mm scale.

Growth inhibition activity of isolated bacterium against pathogenic bacteria

Four pathogenic bacteria such as Aeromonas sp., Acinetobacter sp., Salmonella sp. and Escherichia coli were used as test microorganisms for this experimentbecause these bacteria cause serious diseases in human body. In this study, Luria broth (LB) liquid and Luria broth (LB) agar medium were used as culture medium for the growth of bacteria. For preparation of culture plates, Luria broth agar medium was prepared and autoclaved at $121^{\circ} \mathrm{C}$ for $20 \mathrm{~min}$. Then the sterilized medium was poured in equal amount (about $20 \mathrm{ml}$ ) in each autoclaved petri-dish and were allowed to cool and solidify. Each test bacterial fresh culture was transferred to separate petri-dish with the help of micropipette in an aseptic condition and were smeared gently to assure homogenous distribution of the test bacteria. The discs (6mm diameters) were made by punching the Whatman No. 1 filter paper. For testing the growth inhibition activity of isolated probiotic bacteria against one pathogenic bacterial sample, paper discs were soaked with different concentrations of isolate $(50,100$, $150,200 \mu \mathrm{l})$. By means of a pair of sterile forceps, the dried discs were placed gently on the solidified agar plates seeded with the test bacteria to ensure contact with the medium. The plates were then kept in an incubator at $37^{\circ} \mathrm{C}$ for $24 \mathrm{~h}$.
After incubation, growth inhibition activities of isolated bacterium was determined by measuring the diameter of inhibitory zones with a millimeter scale. The experiment was repeated three times for the accuracy of results.

\section{Results and discussion}

\section{Isolation of probiotic bacteria}

From all mixed bacterial culture plates, one colony was isolated and identified which was cream colored colony. That colony was isolated by sub-culturing onto fresh LB plates and purified by restreaking further on nutrient agar medium (Fig.1) and incubated for $18-24 \mathrm{hr}$ at $37^{\circ} \mathrm{C}$. Following overnight incubation, the isolate was preserved in $30 \%$ glycerol at $-20^{\circ} \mathrm{C}$.

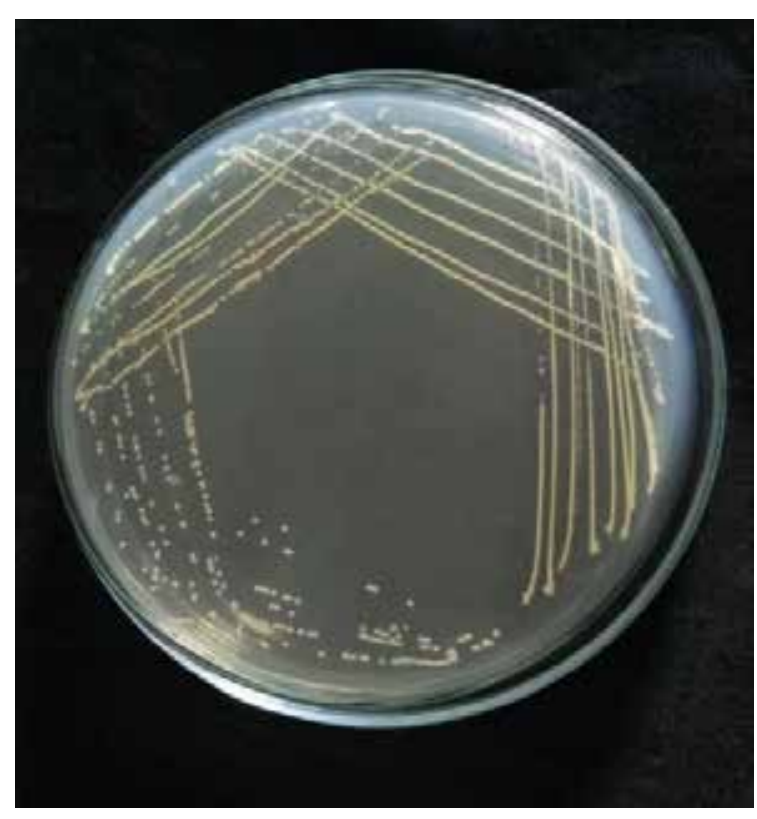

Fig. 1. Streaking plate of isolated bacterial pure culture

\section{PCR amplification and sequencing of 16S rRNA genes}

The homology of the $16 \mathrm{~S}$ rRNA gene sequence was checked with the 16S rRNA gene sequences of other organisms using the BLASTN (http:// www. ncbi.nih. gov/ BLAST) algorithm.Isolated bacteria produced $90 \%$ identity with the $16 \mathrm{~S}$ rRNA gene sequencing of Bifidobacterium sp. DNA quantification analysis and PCR band of isolated bacterium was shown in Fig. 2 and Fig. 3, respectively. 


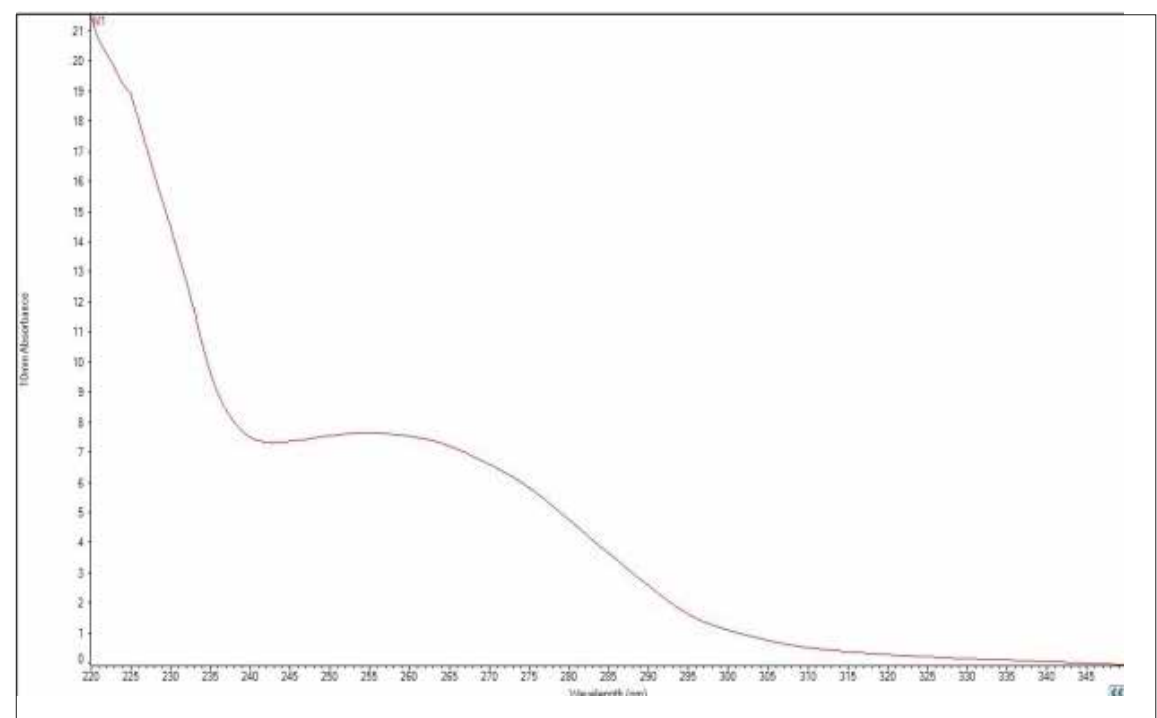

Fig. 2. DNA quantification analysis of the isolate

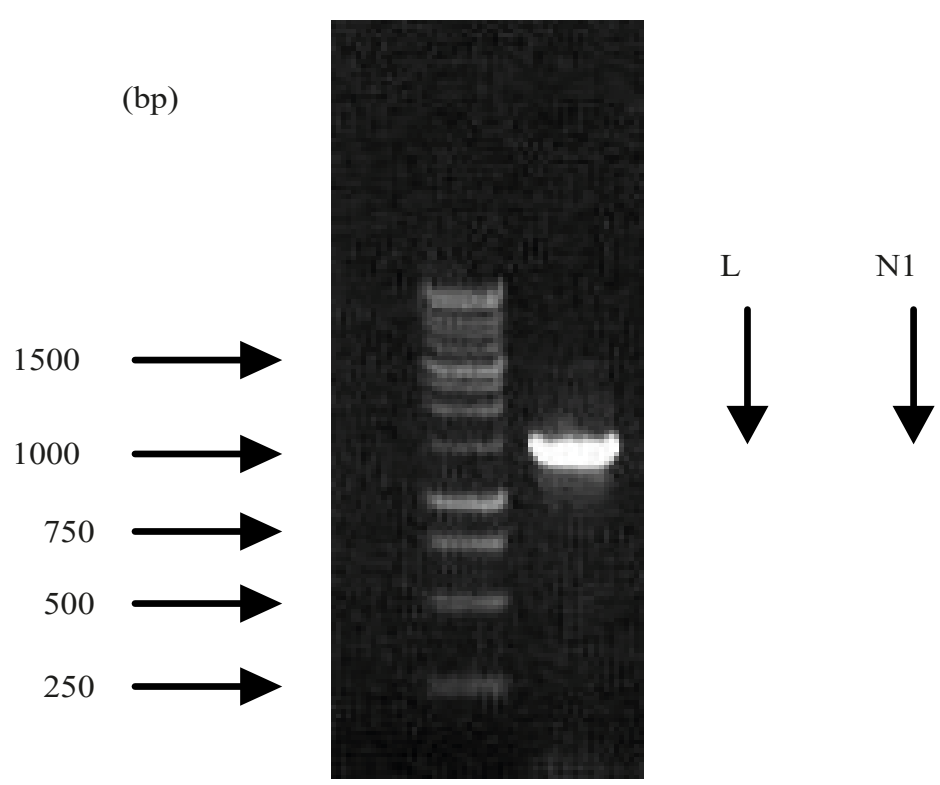

Fig. 3. 16S rRNA gene profiling of the isolate (N1) using $27 \mathrm{~F}$ and $1492 \mathrm{R}$ primers. $\mathrm{L}$ denotes $1 \mathrm{~kb}$ DNA ladder (marker)

\section{Antibiotic sensitivity test}

The sensitivity of probiotics to conventional antibiotics is a fundamental health-promoting characteristic. In our present study, Bifidobacterium sp. was sensitive to erythromycin, kanamycin, gentamycin, tetracycline, ciprofloxacin, doxycycline and resistant against penicillin, amoxicillin, ceftazidime, cefuroxime (Table I and Fig. 4). Masco et al. (2006) found that Bifidobacterium sp. from probiotic products exhibited high sensitivity to tested antibiotics. In their study, Bifidobacterium sp. isolated from probiotic products were sensitive to amoxicillin, ciprofloxacin, erythromycin, rifampicin, tetracycline and resistant to gentamycin, polymixin B. It was noteworthy that antibiotic susceptible 


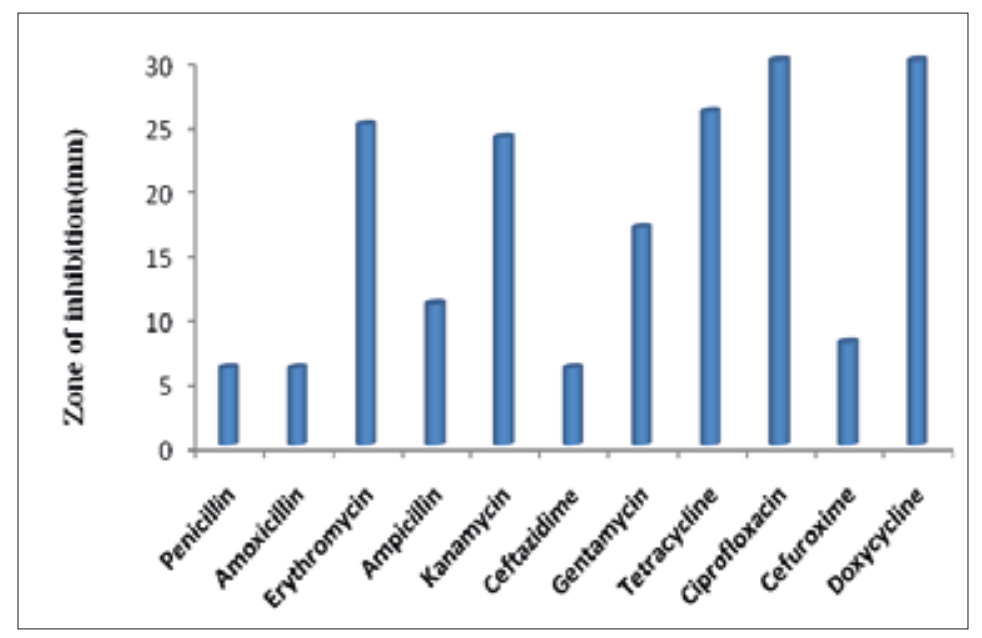

Fig. 4. Antibiotic sensitivity pattern of the isolate identified as Bifidobacterium sp.

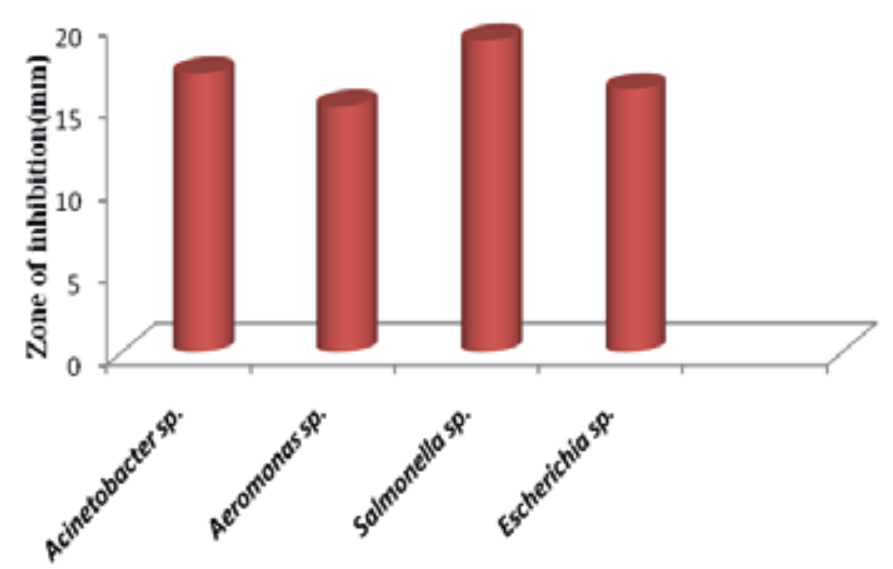

Fig. 5. Growth inhibition activity of the isolate identified as Bifidobacterium sp. against pathogenic bacteria at dose of $200 \mu \mathrm{l} / \mathrm{disc}$

Bifidobacterium sp. was isolated from homemade yoghurt (Ralitsa et al., 2015). According to their investigation, all isolates were sensitive to amoxocillin, gentamycin, erythromycin and tetracycline. Our result showed similarity with previous findings.

Growth inhibition activity of isolated bacterium against pathogenic bacteria

Antimicrobial activity is a very important criterion for selection of starter and probiotic culture as natural antagonists of potentially harmful bacteria. The present study explored the growth inhibition activity of isolated
Bifidobacterium sp. against pathogenic bacteria with four different doses like 50, 100, 150 and $200 \mu \mathrm{l} /$ disc. In case of isolated bacterium, Acinetobacter sp. and Escherichia sp. were susceptible at dose of $200 \mu \mathrm{l} /$ disc with $17 \mathrm{~mm}$ and $16 \mathrm{~mm}$ zones of inhibition, respectively (Table II and Fig. 5). In addition to that, Salmonellasp. was susceptible with inhibition zones of $16 \mathrm{~mm}$ and $19 \mathrm{~mm}$ at doses of 150 and $200 \mu \mathrm{l} /$ disc, respectively (Table II and Fig. 5). But isolated Bifidobacterium sp. exhibited no susceptible zone of inhibition against Aeromonas sp. (Table II and Fig.5). According to Denkova et al. (2005) Bifidobacterium sp. isolated from different sources were able to inhibit the growth of Escherichia coli, Salmonellasp and Klebsiella 
Table I. Summarized result of antibiotic sensitivity test of isolate identified as Bifidobacterium sp.

\begin{tabular}{lcc}
\hline $\begin{array}{c}\text { Name of } \\
\text { antibiotic }\end{array}$ & $\begin{array}{c}\text { Zone of } \\
\text { inhibition }(\mathrm{mm})\end{array}$ & $\begin{array}{c}\text { Resistance } \\
\text { pattern }\end{array}$ \\
\hline Penicillin & $6 \mathrm{~mm}$ & Resistant \\
Amoxicillin & $6 \mathrm{~mm}$ & $\begin{array}{l}\text { Resistant } \\
\text { Erythromycin }\end{array}$ \\
Ampicillin & $25 \mathrm{~mm}$ & Susceptible \\
Kanamycin & $11 \mathrm{~mm}$ & Intermediate resistant \\
Ceftazidime & $64 \mathrm{~mm}$ & Susceptible \\
Gentamycin & $17 \mathrm{~mm}$ & Resistant \\
Tetracycline & $26 \mathrm{~mm}$ & Susceptible \\
Ciprofloxacin & $30 \mathrm{~mm}$ & Susceptible \\
Cefuroxime & $8 \mathrm{~mm}$ & Susceptible \\
Doxycycline & $30 \mathrm{~mm}$ & Resistant \\
\end{tabular}

Note: Resistant $=<10 \mathrm{~mm}$; Intermediate $=10-15 \mathrm{~mm}$; Susceptible $=>15$

Table II. Growth inhibition activity of the isolate identified as Bifidobacterium sp. against four pathogenic bacteria

\begin{tabular}{|c|c|c|c|}
\hline $\begin{array}{c}\text { Name of test } \\
\text { bacteria }\end{array}$ & Dose $(\mu 1 /$ disc $)$ & $\begin{array}{l}\text { Zone of inhibition }(\mathrm{mm}) \\
\text { Bifidobacterium } \mathrm{sp} .\end{array}$ & $\begin{array}{l}\text { Resistant pattern } \\
\text { Bifidobacterium sp. }\end{array}$ \\
\hline \multirow{3}{*}{ Acinetobacter sp. } & $\begin{array}{c}50 \\
100\end{array}$ & $\begin{array}{l}9 \\
11\end{array}$ & $\begin{array}{l}\text { Resistant } \\
\text { Intermedia te resistant }\end{array}$ \\
\hline & 150 & 14 & Intermediate resistant \\
\hline & 200 & 17 & Susceptible \\
\hline \multirow{4}{*}{ Aeromonas sp. } & 50 & 6 & Resistant \\
\hline & $\begin{array}{l}100 \\
150\end{array}$ & $\begin{array}{l}8 \\
11\end{array}$ & $\begin{array}{l}\text { Resistant } \\
\text { Intermediate resistant }\end{array}$ \\
\hline & 200 & 15 & Intermediate resistant \\
\hline & 50 & 11 & Intermediate resistant \\
\hline \multirow[t]{2}{*}{ Salmonella sp. } & $\begin{array}{l}100 \\
150\end{array}$ & $\begin{array}{l}13 \\
16\end{array}$ & $\begin{array}{l}\text { Intermediate resistant } \\
\text { Susceptible }\end{array}$ \\
\hline & $\begin{array}{r}200 \\
50\end{array}$ & $\begin{array}{l}19 \\
7\end{array}$ & $\begin{array}{l}\text { Susceptible } \\
\text { Resistant }\end{array}$ \\
\hline \multirow{3}{*}{ Escherichia coli } & 100 & 10 & Resistant \\
\hline & 150 & 13 & Intermediate resistant \\
\hline & 200 & 16 & Susceptible \\
\hline
\end{tabular}


pneumonae. Another study of Bayar et al. (2018) confirmed that probiotic lactic acid bacterial strains showed antimicrobial activity against Escherichia coli, Salmonella typhimurium, Staphylococcus aureus species by producing zones of inhibition ranged from $10 \mathrm{~mm}$ to $22 \mathrm{~mm}$ diameter at dose of $100 \mu \mathrm{l} / \mathrm{disc}$. Our result had resemblance with previous findings. From the result it was clear that isolated probiotic strains can produce antimicrobial product which can restrain the growth of pathogenic bacteria.

\section{Conclusion}

From the present study, it was observed that isolated probiotic bacterial strain had growth inhibition activity against human pathogens. It should be studied further as biotherapeutic agents for treatment of specific disease conditions. In addition, sensitivity or intrinsic resistance of the majority of the strains to a recommended set of antibiotics make them safe for use in different products for human or animal consumption.

\section{References}

Baivati B, Vescovo M and Torriani S (2000), Bifidobacteria: history, ecology, physiology, and applicaton, Annals Microbiol. 35: 117-131.

Bauer AW, Kirby WM, Sherris JC and Turek M (1966), Antibiotic susceptibility testing by a standardized single disk method, Am J Clin Pathol. 45(6): 493-496.

Bayar E, Demberel S, Satomi I, Kensuke M and Takashi Y (2018), Antibacterial activity of Bifidobacteria isolated from infant faces, Proc Mong Acad Sci, 58(3): 44-52.

Denkova R, Denkova Z, Yanakieva V and Blazheva D (2015), Antimicrobial activity of probiotic lactobacilli, bifidobacteria and propionic acid bacteria isolated from different sources, Microbial pathogens and strategies for combating them: science, technology and education, pp 857-864.

Fijan S (2016), Influence of the growth of Pseudomonas aeruginosa in milk fermented by multispecies probiotics and Kefir microbiota, J Probiotics Health. 3: 136-140. DOI: 10.4172/2329-8901.1000136
Gomes AMP and Malcata FX (1999). Bifidobacterium spp. and Lactobacillus acidophilus: biological, biochemical, technological and therapeutical properties relevant for use as probiotics, Trends Food Sci. Technol. 10: 139-157. DOI: org/10.1016/ S0924-2244(99)00033-3

Hassanzadazar H, Ehsani A, Mardani K and Hesari J (2012), Investigation of antibacterial, acid and bile tolerance properties of lactobacilli isolated from Koozeh cheese, Vet Res Forum. 3: 181-185.

Hill C, Guarner F, Reid G, Gibson GR, Merenstein DJ, Pot B, Morelli L,Canani RB, Flint HJ, Salminen S, Calder PC and Sanders ME (2014), Expert consensus document. The International Scientific Association for probiotics and prebiotics consensus statement on the scope and appropriate use of the term probiotic, Nat Rev Gastroenterol \& Hepatol. 11(8): 506-514.

Makras L and Vuyst LD (2006). The in vitro inhibition of Gram-negative pathogenic bacteria by bifidobacteria is caused by the production of organic acids, Int Dairy J. 16: 1049-1057. DOI: org/10.1016/ j.idairyj. 2005.09.006

Masco L, Hoorde KV, Brandt ED, Swings J and Huys G (2006), Antimicrobial susceptibility of Bifidobacterium strains from humans, animals and probiotic products, $J$ Antimicrob Chemother. 58(1): 85-94. DOI: org/10.1093/jac/dkl197

Matsuki T, Watanabe K, Fujimoto J, Kado Y, Takada T, Matsumoto K and Tanaka R (2004), Quantitative PCR with 16S rRNA-gene-targeted species-specific primers for analysis of human intestinal bifidobacteria, Appl Environ Microbiol. 70: 167-173. DOI: org/10.1128/AEM.70.1.167-173.2004

Pundir RK, Rana R, Kashyap N and Kaur A (2013), Probiotic potential of lactic acid bacteria isolated from food samples: an in vitro study, $J$ Appl Pharma Sci. 3: 85-93. DOI: 10.7324/JAPS.2013.30317

Ralitsa G, Lyubomira Y, Lilia T, Galina Z, Nina S, Akseniya A, Antonia D, Gergana I, Nikolay K, Nevenka R and Elena K (2015), Antimicrobial activity and antibiotic susceptibility of Lactobacillus and Bifidobacterium sp. intended for use as starter and probiotic cultures, 
Biotechnol Biotechnol Equip. 29(1): 84-91. DOI: org/10.1080/13102818.2014.987450

Reyhaneh M, Rahim N, Hamed Z, Tahereh T, Horieh S and Parviz O (2018), Screening and characterization of in-vitro probiotic criteria of Saccharomyces and Kluyveromyces strains, Iran J Microbiol. 10(2): 123-131.

Shah SU (2012). Importance of genotoxicity and guidelines for genotoxicity testing for pharmaceuticals, IOSR $J$ Phar Bio Sci. 1(2): 43-54.

Shahnaz P, Shimazaki K and Kato I (2004), Milk and milk products in Bangladesh, $J$ Rakuno Gakuen Uni. 29: 9-16. DOI: $10.22004 /$ ag.econ.208737
Sultana JM, Refaya R, Shajidur R and Kohinur B (2017), Isolation and biochemical characterization of Lactobacillus species from yogurt and cheese samples in Dhaka metropolitan area, Bangladesh Pharm J. 20(1): 27-33. DOI: org/10.3329/bpj.v20i1.32090

Tabanelli G, Verardo V, Pasini F, Cavina P, Lanciotti R and Caboni MF (2016), Survival of the functional yeast Kluyveromyces marxianus B0399 in fermented milk with added sorbic acid, J Dairy Sci. 99: 120-129. DOI: org/10.3168/jds.2015-10084 